\title{
RECONCILING CONTRADICTIONS: BUDDHIST-MUSLIM VIOLENCE, NARRATIVE MAKING AND MEMORY IN MYANMAR
}

\author{
Matt Schissler*, Matthew J. Walton** and Phyu Phyu Thi*** \\ * Department of Anthropology, University of Michigan, Ann Arbor, Michigan, United States \\ ** (corresponding author) St Antony's College, University of Oxford, 62 Woodstock Rd. Oxford \\ OX2 6JF, United Kingdom
}

Email: matthew.walton@sant.ox.ac.uk

*** Myanmar ICT for Development Organization, Yangon, Myanmar

\begin{abstract}
Myanmar has been the site of serious violence between Buddhist and Muslim communities. This article presents findings from a research project convened to better understand the production of this violence. Based on interviews with 78 residents of six cities, we find a narrative that presents Islam in general and Muslims in Myanmar as an existential threat to "race and religion" and a personal threat to individuals and communities. This narrative is reinforced by three inter-related sets of arguments that refer to international events, events within Myanmar, and personal experiences. Drawing on these findings, we explore the ways in which Muslims in Myanmar are constructed as a "fearsome Other," thus justifying discrimination and violence. However, we also identify alternative narratives that contest the production of violence. These narratives are generated through articulated senses of contradiction between contemporary antagonisms and memories of inter-religious coexistence. We argue that understanding these narratives is one necessary part of much larger efforts to promote peace and reconciliation.
\end{abstract}

\section{Keywords}

Myanmar, Buddhism, Islam, narratives, memory, violence

In recent years, Myanmar has been the site of serious violence between Buddhist and Muslim communities, particularly in Rakhine State, where at least 146,000 persons have been displaced since riots in June 2012 (UNOCHA 2015). This violence has been the subject of international English-language media coverage as well as responses by diplomats and the United Nations (UN), including a closed-door briefing on Myanmar at the Security Council (Reuters, May 28, 2015). International attention has tended to focus on the situation for Muslims who seek to be recognised as ethnic Rohingya, periodic riotous violence, and the extreme anti-Muslim rhetoric of some Buddhist leaders. As far 
back as 2013, but with increasing frequency, international organisations dedicated to monitoring and early warning of mass violence have been issuing alarms. These include the International State Crime Initiative at the University of London, which says it has found evidence that violence has been organised and has moved through four identified stages of preparation for genocide (Green, MacManus, and de la Cour Venning 2015). “The parallels to the Nazi genocide are striking,” George Soros (2015) told attendees at a conference the Norwegian Nobel Institute hosted in Oslo during May 2015. The conference also included an appeal from three Nobel laureates to stop violence and persecution in Myanmar that they called "nothing less than genocide” (The Guardian, May 31, 2015).

Buddhist-Muslim violence has included acts of extraordinary brutality, including a massacre of children (Physicians for Human Rights 2013), mutilation of bodies and desecration of religious sites. ${ }^{1}$ These are acts that make up the outer limits of what human beings can do to other human beings. But, to understand such acts of violence, Bourgois and Scheper-Hughes $(2003,19)$ have argued that we must also pay close attention to "little violences," those that are "produced in the structures, habituses, and mentalitiés of everyday life.” This violence makes up a continuum, they argue, which hinges on "the human capacity to reduce others to nonpersons, to monsters, or to things that gives structure, meaning, and rationale to everyday practices of violence” (Scheper-Hughes 2002, 369). And indeed, even for those arguing that the criteria for the legal definition of genocide have all already been met in Myanmar, much of the basis for this conclusion is not in the extreme examples of riots and massacres but in the sustained impacts of policies and practices of persecution that are resulting in the destruction of Muslim communities in Rakhine State (Allard K. Lowenstein International Human Rights Clinic 
2015; Green, MacManus, and de la Cour Venning 2015). One analysis has thus labelled the situation “a slow burning genocide” (Maung Zarni and Cowley 2014).

This article seeks to understand violence not only as sporadic instances of brutality such as riots but also as the sustained policies and practices of discrimination (Farmer 2004, 315). Violence may be subtle and ordinary —it may be a constitutive dimension of states and social order as much as it may constitute their rupture (Coronil and Skurski 2006, 3; see also Benjamin 1986). But such violence produces death and suffering even where its operation is less visible. This is apparent in the research cited above on Rakhine State. But we would add that concern for violence in Myanmar must also account for the fact of its potentiality. Some people are defined into groups such that they are always vulnerable, subject to the possibility of violence even when they do not come to physical harm (Butler 2003, 10; Galtung 1969, 172). This article seeks to understand how a group in Myanmar is being defined and exposed to violence, whether it takes the form of riots, discrimination or the precarity associated with persistent potential attack.

Developing such an understanding must consider the full continuum of violence detailed by Bourgois and Scheper-Hughes (2003). We also draw inspiration from the work of Das (1998), who has described similar processes in her exploration of Hindu-Sikh violence in India in the 1980s. In her research Das marks an important shift: when "fear of the other is transformed into the notion that the other is fearsome" (Das 1998, 125). Das's argument is that for violence at the most extreme end of Scheper-Hughes's (2002) continuum to be made possible, there must be a shift in which the Other is made categorically fearsome. The difference is subtle but important: the category of a fearsome Other is what enables violence to be exacted on all those who can be placed within such a 
category. This is the difference between a dynamic in which particular members of groups are marked as threatening and one in which all who fit within the category Other are, by virtue of their existence, a threat. In an impressive synthesis of literature on mass violence, Leader Maynard (2014) has identified this dynamic as common to examples of mass violence across time and space. In war, for example, members of particular groups may be marked as threatening, but others of the same group may not. Violence of another order becomes possible when all who meet a category are deemed synonymous with threat as a function of their existence. To be made a fearsome Other, in other words, is to be always potentially subjected to violence as a condition of being Other (see Cheeseman 2017).

This article identifies a persistent narrative in Myanmar that constructs Muslims as a fearsome Other. Its basic premise is consistent with existing scholarship on the issue (Gravers 2015; Kyaw San Wai 2014; Nyi Nyi Kyaw 2016; Walton and Hayward 2014). However, we believe that studying this narrative in more detail is a necessary part of advancing this understanding in two ways. First, by tracing the ways that everyday discourses about Muslims are situated locally, nationally, and globally to justify a sense of threat that is defined explicitly in terms of religious identity. ${ }^{2}$ Second, to argue that the foundations for a powerful alternate narrative can also be identified, drawing on the way people articulate their own memories of inter-religious life. Such articulations raise important questions for the study of Buddhist-Muslim violence in Myanmar.

We focus this article on the construction of narratives about Muslims by non-Muslims in Myanmar because we believe that understanding the production of such narratives is necessary if responses are to be crafted that help to lessen violence or promote peace and 
reconciliation. Similarly, understanding the ways narratives are being mobilised is important so that they are not unintentionally strengthened. Discourse about violence in Myanmar can contribute to the mobilisation of that violence and scholars who write about Myanmar must consider the relationships between what they write and the production of violence (Cheesman 2017). Such considerations are impossible without listening to the ways non-Muslims discuss Muslims in everyday life. Listening need not equate with agreement, nor entail ignoring marginalised minorities. But it is necessary because it will lead to better responses, and because it is an ethical matter and small way to de-escalate a growing sense among Buddhists that their fears and perceptions are being ignored.

People who are Muslim in Myanmar are diverse, however, and it would be valuable to explore the perspective of these individuals. Peacebuilding would also be furthered by a deeper understanding of the way that "Buddhists" are categorised, along with the way that different Muslim groups position themselves. Such research is necessary, but this article is tailored more narrowly to understanding narratives about the category "Muslim,” primarily as presented by people who are defining this category as threatening. This article is thus primarily about the way people who are Buddhist discussed people who are Muslim, though we do not seek to quantify a "Buddhist viewpoint” and in a few places we make reference to our interviews with people from other religious communities.

This article is based upon interviews conducted during the first half of 2015 as a part of the Myanmar Media and Society Project (M.MAS), as well as other ongoing research and publications by the authors (Schissler 2016a, 2016b; Schonthal and Walton 2016; Walton, McKay and Khin Mar Mar Kyi 2015; Walton, Schissler and Phyu Phyu Thi 
2017). ${ }^{3}$ This article is not an argument about the percentage of the population that feels in a particular way. Rather, we identify two important lines of discourse and seek to understand how they are being constructed. We begin with a brief discussion of the project's methodology. The subsequent section details the narrative of Muslims as a fearsome Other that we have identified, and explores the relationship between this narrative and violence. It is followed by a section where we describe the senses of contradiction encountered, where people sought to reconcile contemporary violence and tensions between groups with articulated memories of inter-religious co-existence. This leads to a final consideration of the ways in which the historical lineage of contemporary violence is being constructed—and could be contested or re-shaped.

\section{LISTENING IN SIX MYANMAR CITIES}

During February, March and April 2015 the authors conducted 68 interviews with 78 persons across six research areas. These areas included four cities that have experienced recent violence (Sittwe, Meiktila, Mandalay and Lashio) and two that have not (Pathein and Mawlamyine). ${ }^{4}$ Methodologically, it can be challenging to investigate the ways in which narratives about violence are produced. Such challenges are accentuated by the fraught contemporary context. Moreover, it is important not to presume that BuddhistMuslim "communal conflict” is of central concern to people in Myanmar, or that people necessarily understand violence that has occurred to date as "communal" or define it in religious terms as Buddhist versus Muslim (Pandey 1998). These concerns prompted us to adopt a "Listening Project” approach. 
Interviews were conducted with subjects (referred to as "narrators") according to a loose but consistent format consisting of three parts. The first questions aimed to establish familiarity. These questions focused on biographical information, including work and voluntary activities, experience living or travelling in other parts of Myanmar, and familiarity with "other people," that is, people of other ethnicities, religions or geographic origin. The second set of questions asked people to share their concerns for the country. After working with them to develop between three and five concerns, we then asked them to choose their primary concern and then probed to more fully explain their concerns. When follow up questions were necessary to prompt further discussion, these included “what are you worried might happen?” "how long have you been worried about this?” (or, “when did you start worrying about this?”), and “where did you learn about this?” or “with whom do you discuss this?” After engaging in this discussion, we then repeated the process, but positioned the questions as about the narrator's local area. Finally, the third set of questions asked about the narrator's hopes for the future and offered an open time for them to add anything else they felt to be important. We conducted our interviews in Burmese and arranged translations only when, in a few cases, we spoke with individuals who felt more comfortable speaking in another language.

In making decisions about who to interview, we set a quota to ensure that the interview pool was diverse in terms of gender, age, religion, and class. We also maintained a generally even division between ethnic Bamar and non-Bamar narrators. In parallel to our research we also conducted a training programme for young activists, who also helped us to arrange interviews. As residents of each research area, they sought to meet our criteria while managing to avoid risks associated with discussing potentially tense topics in already tense environments. Overall, the full set of interviewees was a convenience 
sample, but in such a setting "convenience” should be understood to mean individuals who were willing to discuss what they saw as major problems facing the country and to do so with a research team that included a foreigner. Individuals interviewed by the authors are summarised in Table 1 below; interviews were usually with one person, but in a few cases narrators felt more comfortable being interviewed along with one or two other persons.

Table 1. Individuals interviewed

\begin{tabular}{|c|c|c|c|c|c|c|c|c|c|}
\hline City & $\begin{array}{c}\text { No. of } \\
\text { Interviews }\end{array}$ & Men & Women & Over 40 & Under 40 & Buddhist & Christian & Hindu & Muslim \\
\hline Lashio & 13 & 8 & 8 & 4 & 12 & 7 & 2 & 3 & 4 \\
\hline Mandalay & 8 & 4 & 7 & 4 & 7 & 6 & 2 & 1 & 2 \\
\hline Mawlamyine & 13 & 8 & 5 & 3 & 10 & 5 & 2 & 3 & 3 \\
\hline Meiktila & 9 & 6 & 5 & 7 & 4 & 4 & 1 & 4 & 2 \\
\hline Sittwe & 16 & 13 & 5 & 11 & 7 & 10 & 1 & 2 & 5 \\
\hline Pathein & 9 & 5 & 4 & 4 & 5 & 7 & 0 & 1 & 1 \\
\hline Totals & 68 & 44 & 34 & 33 & 45 & 39 & 8 & 14 & 17 \\
\hline
\end{tabular}

The interview approach was designed to open a conversation about concerns related to Buddhist-Muslim violence, while seeking to avoid presuming that this was a salient issue for narrators. Whether we succeeded in keeping the conversation wholly open-and whether such an interview encounter is ever possible-our interest was not in ascertaining or quantifying a ranking of national or local concerns and locating religious violence. Instead, we wanted to create an environment that was conducive to conversations about the issue of conflict and provide a sense of how conflict is present within the fluctuating constellation of concerns that any person has at a given time. As might be expected, people raised a variety of concerns. But nearly everyone raised, in 
some fashion, concerns about religious violence. ${ }^{5}$ Ultimately, our method enabled us to have nearly 70 wide-ranging conversations about religious violence across six locations. The next two sections detail what was learned from these conversations, with a focus on how those who expressed fear and antagonism towards Muslims explained their feelings.

\section{Muslims as fearsome Other}

The Government of Myanmar under President U Thein Sein was quick to reject allegations regarding violence against Muslims and has steadfastly refused citizenship for any people that identify as Rohingya. ${ }^{6}$ For example, following the May 2015 Oslo conference mentioned above, the Ministry of Foreign Affairs published a statement calling the proceedings “unbalanced and negative” (The Guardian, May 31, 2015). This response mirrored the way that the state has long responded to external criticisms of the country's human rights record and in that sense it was not particularly unusual. But the response by U Zaw Aye Maung, then the Rakhine Affairs Minister for Yangon Region, was more telling; a few days after the Oslo conference, he was quoted by the Reuters news agency as saying, "if genocide was taking place in Rakhine State, then it was against ethnic Rakhine Buddhists” (cited in Reuters, June 5, 2015).

U Zaw Aye Maung's statement is telling because it illustrated a conception of who is under threat and who has been the aggressor that is diametrically opposed to the one made visible in international discourse (Brooten and Verbruggen 2017). There are, of course, many conceptions of violence in Myanmar, but while U Zaw Aye Maung's statement appears extreme in comparison to international discourses, in the domestic context this is not the case. "Fear is not just on the side of the Muslims, but on the side of 
the Buddhists as well,” Aung San Suu Kyi explained to the BBC in October 2013.

“There’s a perception that Muslim power, global Muslim power, is very great” (BBC News, October 24, 2013). These perceptions are voiced powerfully by public figures and Buddhist leaders from groups including the 969 Movement and Organisation for the Protection of Race and Religion (known by its Burmese acronym MaBaTha). These groups have risen to prominence since 2013 as they have mobilised to project an existential threat, in which Buddhism is vulnerable and needing protection lest it be supplanted by Islam. Internationally, the most extreme examples of their speech have attracted media attention, including references to Muslims as “rabid dogs” and invasive species (see TIME, July 1, 2013). Domestically, they established themselves as forces with clear and powerful social and political influence. Their iconography is visible across Myanmar and they have successfully influenced law-making, protesting development projects at Shwedagon Pagoda in Yangon and winning passage through parliament of a package of four "race and religion protection” laws for which they also garnered millions of signatures. They have also participated in, organised, or supported vocal demonstrations in Yangon, Mandalay and Sittwe supporting their proposed legislative agenda and opposing "biased,” "pro-Muslim” or "pro-Rohingya” activities by the UN, the Organisation of Islamic Conference and international non-governmental organisations (see The Irrawaddy, June 22, 2015).

What has received less attention, however, is the way that people speak about BuddhistMuslim violence in everyday life. Our research was in part motivated by this fact and enabled us to identify a persistent set of arguments made by people who seemed to view Muslims as a fearsome Other. These arguments operated as a narrative framework that presented Muslims as both an existential threat to race and religion and a personal threat 
to the interviewees or their communities. Narrators repeatedly referenced the vulnerability of Buddhism or a particular ethnic community to being erased or supplanted. Variants on the phrase “one people swallowing another” were regularly used, for example, invoking a slogan used by the Ministry of Immigration and Population: “A nation will not disappear even if it is swallowed up by the earth. But a nation will disappear if it is swallowed up by another people."7

The narrators described Muslims as violent and untrustworthy. This entailed an understanding of Islam in unitary terms, as a homogenous and universal category. Islamic religious practices were referenced to prove this, in terms both general - "Islam is an ideology of violence” - and specific. Cow butchering was a common example. ${ }^{8}$ Even for those Buddhists who eat beef, that Islam would require butchering a revered animal is taken as a powerful statement about violence embedded within the religion. Prominent 969 and MaBaTha monk U Wirathu has made similar statements, arguing that the halal way of killing cattle "allows familiarity with blood,” thus making a direct connection between Islamic religious tradition and an imagined capacity for violence (see The Guardian, April 18, 2013).

Another common example given was the position of women, especially their perceived maltreatment and lack of freedoms within Islam.

A: Among the religions, Islam is resentful, because if you marry one woman, you can marry her sister, and also her other relatives. I have seen that. They have those kinds of habits... For that reason, I do not like Islam religion, and they are bad. Q: How? 
A: They are bad, if it is related to females. They destroy the girls, to be frank. They have those habits, for us, we care as brothers and sister but for them they would like to take advantage in any circumstances (Man, 54, Hindu-Buddhist, “Thitagu,” Mawlamyine March 2015). ${ }^{9}$

In conceiving of Islamic religious practices, narrators also constructed an image of Muslims in which being devout is equivalent to being violent. That is, the image was of "Muslims” as an Other, dangerous because of religious belief. Outward indications of religious devotion such as the sound of prayer or clothing choices, then, were read not just as markers of difference but of "extremism" and the potential for violence. The following excerpt from an interview with a young Buddhist man in the Ayeyarwady Delta illustrates the connection drawn between views of Muslim devotion and “extremism”:

My aunt's husband is Muslim... As he is my aunt's husband, we tried to see him as an uncle at first. Later, what happened was, they are very good at mobilising for their religion. They are very religious people... For them, from children to old people, they only trust their god. Then, eventually, they persuaded my aunt to their religion. At first, my aunt worshipped [Buddha] but later, she did not. He would persuade her with different ways until he got it. Now, she and the children who she gave birth to became Muslim... I was also a friend with an Islam [Muslim]... However, as I observed his behavior and his beliefs, I noticed that he was very serious in his religious belief. To say it rudely, he was like an extremist. I didn’t discuss this with him... I just lived innocently with him. If he asked me, I talked to him and if he called me, I answered... However, I was not comfortable. 
He is from a different religion and also an extremist... At that time, I really wanted to do something to him but I tried to control myself. Later, it was fine. I just let it go and didn’t argue with him much (Man, 20, Buddhist, Myanmar, Pathein February 2015).

In this example devotion, understood as synonymous with extremism, helped to establish the nature of a perceived Muslim threat: all devout Muslims are potentially dangerous. This aligned with the idea that Muslims seek to expand and overtake other religions, as a function of a colonising imperative, or an unwillingness to assimilate, asserted to originate within Islamic teaching. Some narrators explained this as the meaning of Jihad or a requirement contained within Sharia. Both words were in common usage, though understandings of their meaning may vary and may not conform to understandings of these concepts within Islamic traditions. A few narrators situated such claims historically, with references to countries such as Afghanistan or Indonesia, places that were stated to have once been Buddhist but which are now Muslim. Narrators explained this specter of a "Muslim takeover" as potentially occurring through a variety of mechanisms that require vigilance on the part of Buddhists. The argument seemed to be primarily demographic and based on ideas of rapid Muslim population growth driven by large families, intermarriage and forced conversion of Buddhist women, illegal immigration from Bangladesh and the use of violence or economic power.

\section{Justifying arguments}

The arguments that Islam is violent and that Muslims present an existential or personal threat can be loosely grouped into three interrelated strands: references to international 
events, events within Myanmar and personal experiences. We use the term "argument” here because, by asking narrators to choose their primary concerns and then explain them, the interview encounter obliged narrators to justify their choices. This sense of argument manifested differently among narrators, but some went so far as to invest clear energy into not only answering our questions but into attempting to secure our agreement. In Lashio, for example, we interviewed a mother who works at the central office of the Shan State MaBaTha. She spoke to us earnestly, sometimes seeming to be on the verge of tears, and with a high degree of certainty about the information she presented:

In my opinion, for the first point, it is religion. They [Muslims] are swallowing our religion... I am so worried about it for our future generations, our grandchildren and so on. In our time, horrible things like this happen to our religion. For the future of our children, I am so worried that our religion will disappear. I have these worries and concerns. I don't want this religion to disappear for our future generation. I want it to last forever (Woman, 38, Buddhist, Myanmar, Lashio, March 2015).

Given that this woman told us she had left her previous employment to work for MaBaTha because of her desire to protect Buddhism, it is not surprising that she stated her views strongly. She is also, not surprisingly, a particularly illustrative narrator who synthesised and repeated all three strands of arguments we heard others make in varying permutations:

The things that happened took place not far from our work place - members of the other religion rape children about your daughter's age, and we read about that 
in the news and also see it in real life... Their religion is terrorism. They lured people to convert to their religion by force; they don't have freedom of belief in their religion. If a Burmese Buddhist got married to one of them, every opportunity would be lost. Even a drop of blood from them is very dangerous. The blood of terror. They have been taught this since they were children, so it's very terrifying. We say, “don’t kill”... They say, “kill, if you kill you will be blessed...”. Now, in the news, we see about their Jihad in other countries, cutting off peoples’ heads. Horrible things, burning people alive... I don’t want to see our Buddhists suffer like that. That's why I want to show people the horror of their religion. I want everyone to know.

This narrator is making a claim about Islam as a religion that promotes violence and then calling on a variety of examples to illustrate her point. She appears to be referencing the Islamic State of Iraq and Syria (ISIS), as many others did. At the time, references to ISIS were topical, but we also heard mention of a variety of other international events, some of which are described here.

A: I'd like to say that religious conflict is the biggest issue.

Q: Since when do you feel like this religious conflict is the biggest issue for the country?

A: Since the incident happened in Rakhine State, and as the tension has grown recently, the hatred towards Islam has grown. I have concerns for the actions upon [Burma] that will be taken by the middle part.

Q: What do you mean "by the middle part?" 
A: ISIS from the Middle East. If they declare Jihad on Burma, that can be a problem for us as well as the whole ASEAN community. I am worried about it (Man, 26, Buddhist, Myanmar, Mawlamyine, March 2015).

The second strand of argument involved reference to events within Myanmar or the narrator's local area. In many cases this entailed reference to riots, either in Rakhine State or in other places that have been the site of collective violence. Other common references were to incidents of sexual violence or forced conversion of Buddhist women and desecration or disrespect of religious objects such as Buddha statues. In the following excerpt from an interview in a teashop in Sittwe, the narrator invokes a variety of examples to illustrate her point, oscillating between references to incidents during largescale riots and to more quotidian events. As she explained these things to us she grew increasingly animated, even jovial, looking at us and over us to draw in those bystanders not yet included in our conversation:

For them, if Rakhine are bad to them, they just cut the Rakhine’s neck. This is the thing that they preach. We can also hear that... When they preach, they talk like that. They said, “Allah, don’t you see us. What are you doing? Just kill these Rakhine...”. They will act according to whether the situation gives them the chance... At night, they steal people's things... For them [those who live closer to the Muslim area], they cannot even leave their shoes out. They will be stolen... If they kill an Arakan [the narrator used "Rakhine” and "Arakan” to refer to the same ethnicity man and if we catch him [the killer], we do not kill him. We just hand him over to the police. If they catch an Arakan man, they cut his neck and kill him. When there was a conflict, they showed us like this [violent gesture] and 
told us, "we will do this to your Arakan people.” One person from [a nearby area] was killed. They cut off his flesh and cooked and ate it. Then, they cut off his head and showed other people. They are very wicked (Woman, 49, Buddhist, Rakhine, Sittwe, February 2015).

People also said that personal experiences supported their views of Muslims, making up the third strand of argument. For example:

Even for donations, they would ask for donations only to support members of their own religion and they do not care for others. Therefore, I don't buy things from their shop, I only buy from Buddhists... If we buy from a Buddhist shop, it will go to our monks. I don’t want to consume [anything] from them as they are the enemy. When they sleep [facing] in their direction, they are not paying respect to other religions that put their heads in the east to give respect. They put their foot against the things we value... I have lived in the Islamic community; I have studied them a lot. When we ask for water, they would spit [into the cup] first and let you drink. So disgusting... When I was [working as a truck driver], I rented a place in their compound, so I know them well (Man, 54, Hindu-Buddhist, Thitagu, Mawlamyine March 2015). ${ }^{10}$

The following narrator weaves together reference to events abroad and inside Myanmar to explain his generalised fear of Muslims:

Q: Why are you afraid to communicate with Muslims? 
A: They are very strong in racism and always live separately from us. Even if they come and communicate with us, their mind-sets are not honest.

Q: Can you give me some examples?

A: I can give many examples of worldwide incidents. For example, they attacked the World Trade Center in America and you can also see [examples] in Myanmar. They are the sources of these incidents. Nowadays, we are more and more afraid of them and also you can see the situation of ISIS. I don't trust Islam in Myanmar because of this ISIS. For example, Islam [Muslims] from Indonesia are involved in ISIS so nobody can say that Islam [Muslims] in Myanmar are not involved or participating in the processes of ISIS. That is why we are afraid of them (Man, 36, Buddhist, Chinese/Myanmar, Mawlamyine, March 2015).

Importantly, this illustrates how international media accounts diverge from the way we have heard conflict discussed in Myanmar. International accounts position Muslims in Myanmar as primarily victims of violence whereas many of our narrators saw Muslims as perpetrators. This man in Mawlamyine did not go as far as U Zaw Aye Maung and say that the Buddhist Rakhine people have suffered genocide but he- and other narratorsdid present recent instances of conflict as instigated by Muslims who acted as aggressors or who otherwise brought retaliatory violence on themselves.

\section{Virtuous self-defence}

We have chosen to organise our interpretation of these interviews in terms that emphasise the spatial dynamics of the justifying arguments. This emphasises that narrators situated their local and domestic concerns in a global context and illustrates how a dominant 
demographic majority (Buddhists) can fear a demographic minority (Muslims). The concerns presented were with Muslims inside Myanmar as the local embodiment of a global threat seen to surround Myanmar. Aung San Suu Kyi was pilloried by nonBurmese observers for her 2013 BBC interview, but in situating domestic fears in a global context her statement was descriptively accurate (see The Telegraph (UK), October 24, 2013). The fear we heard articulated in Myanmar was not (only) of a small minority and local population, but of a global threat felt to be both descending upon the country and growing within it.

Recall that the key shift in Das' analysis occurs when "fear of the other" becomes "the other is fearsome.” In Myanmar, the arguments we interpreted above regularly displayed this shift. With the narrative of Muslims as a threat established, people described how this prompted them to view individual Muslims with uncertainty and concern; all who satisfy the category "Muslim” also satisfy the category "potential threat” and fearsome Other. The linkage between these views is religion. In Mawlamyine for example, a young ethnic Karen woman we spoke to in a church compound described discussing this feeling with her friends:

A: According to [what I hear from] other people, I am worried that ISIS will affect us, and in our country we have many Muslims. When I see ... [ISIS] cut peoples' heads off, it will be a problem if this comes to us. Some of my friends tell me, if they see Muslims, they are scared of them even though they might not have [plans of cutting peoples' heads off] in their mind. It is like seeing the news about that and then having fear when looking at these people [Muslims in Myanmar]. 
Q: You mention, you are feeling scared, when did you start to feel like that? A: It happened after seeing that news and the Rakhine problem. Since then the news always pops up about it. I am worried that ISIS's actions will affect the world or will affect our country (Woman, 34, Christian, Karen, Mawlamyine, March 2015).

This shift makes a generalised threat specific. When the Other is made fearsome, any Other that one encounters is potentially dangerous. In the context of a sense of threat, beholding a Muslim is thus to see not a person but the embodiment of a threat. Whatever is known about the person as a neighbor or even friend, there is always a potential for aggression and danger and thus, as Butler (2003) describes, must always potentially require or deserve violence. Leader Maynard (2014) has noted that such violence may be normatively allowed or even required with a sense of virtuous self-defence. This paired sense of threat and self-defence showed through in interviews. The woman we spoke with at the MaBaTha office in Lashio told us she does everything she can to warn other Buddhists about the "horror" of Islam. In our trainings with youth activists, they also generated a host of examples illustrating the relationship between a conception of threat and virtuous self-defence. "Killing a kalar is only half a sin,” one participant noted, quoting a popular book. ${ }^{11}$ “Taking action to protect your own race is complying with Buddha’s teachings,” noted another participant, quoting a Buddhist leader. In these sessions, ideologies of threat and virtuous self-defence were, without controversy, considered to be mutually associated.

It should be no surprise, then, that perpetrators of anti-Muslim riots have been described as shouting both "Muslims, be gone” and singing Myanmar's national anthem or 
shouting, "We are Buddhist martyrs" (see The Myanmar Times, July 4, 2015; The New York Times, July 3, 2014). This is not to say that an explanation for riots can be reduced to the rhetorical statements of participants. But as others have suggested, the feelings of those who have not directly participated in violence nonetheless help to shape the degree to which violence is "thinkable," and the degree to which individuals, civil society and the state work either for peace or for continued enmity. In this regard, the narratives discussed above are a basis on which those who do not sufficiently acknowledge or defend against the threat are indicted or attacked. Such attacks have taken the form of both personal harassment and public denouncements by high-profile public figures, as well as shaming campaigns that have become increasingly common on social media. Public figures including social activists, politicians, and government authorities that appear sympathetic to Islam have been subject to such attacks, as have been non-elites in everyday life (see Schissler 2014). Journalists, too, have come under fire for covering violence committed by Buddhists (see The Irrawaddy, June 17, 2015). In these attacks individuals have been framed as traitors who are failing to protect their religion and are marked as betrayers of their religion, race and nation (Schissler 2015).

\section{Contradictions and alternative narratives}

It is important to emphasise again that is not our intention to quantify the degree to which people accept the allegations of threat from Islam or to determine the influence of groups like 969 and MaBaTha. The above discussion is an exploration of the ways people who believe Islam is a threat justified this narrative and what such a narrative may justify in turn. Others interviewed rejected such arguments. Rather than see this as a strict dichotomy between two camps_- “extremists” and “moderates”- it is more useful to 
recognise that people are attempting to navigate everyday lives in which they must both manage their shifting understandings of past and current events and their relationships with people around them. The following excerpt from an interview with a teacher illustrates this point:

For the Rakhine issue, the people who come through the border, how can we call them? Bengali? ${ }^{12}$ They came into the country. As we are bordering other countries, there can be a population flow problem. However, as we couldn’t stop them systematically in the first place, we can't send back the people who are already here. This is not good to say, but I want our country to be a pure Buddhist country. We can allow the other religions, but I want our Buddhist [population] to increase. I can have empathy as a human being but I am also afraid that one ethnic group will swallow another. However, we do not know who started this problem and who is right. For now, I think both sides have made mistakes. If the Rakhine people who I know hear that I have answered in this way, they will hate me (Woman, 42, Buddhist, Karen, Pathein, February 2015).

Interpretation of current and past events is still open and a function of myriad factors: an individual's experiences and social location, memories, understandings of history, information known and relationships with others who may have different and stronger views on the issues in question. Conceptions of threat and anti-Muslim antagonism are actively made, in conversation and contestation with the dynamic views of others and with societal discourses. While many people share the perception of Islam as inherently a threat and thus irredeemably at odds with Buddhists and Buddhism, others are seeking to 
reconcile such a narrative with, for example, memories of religious co-existence and friendship. The teacher from Pathein continued:

Q: When did you start to worry about this issue [religious conflict]?

A: It was when the Rakhine conflict started.

Q: During this time, what kinds of changes have you seen?

A: I think they [Buddhists and Muslims] do not like each other and hate each other... This is what I see but I didn’t ask any other people, so, it’s just my opinion. I think they are being cautious. In the past, they loved each other but now they may have doubts... In the past, families might have very close relationships but now they might be careful and watch each other's steps.

Nearly everyone described their concerns about Islam or inter-religious tension as recent, marking the 2012 riots in Rakhine State or other more recent incidents as the origin point of such a sense. This is not to say that anti-Muslim sentiments did not exist prior to 2012, or that people who are Muslim did not experience violence before this date. ${ }^{13}$ But that almost every person we interviewed in all six cities defined their concerns as relatively recent is important to recognise because, for each person, this articulated sense of prior co-existence entailed a sense of contradiction. This meant that what they said of their memories did not match what they said of current relations between Buddhist and Muslim communities. This sense of contradiction thus required that they do subsequent interpretive work:

Before I joined this association [MaBaTha], I felt that we are all the same human beings in my heart... There was no discrimination in my mind. Not only I felt this 
way, all Buddhists have this same feeling. But after the [riots in May 2013] took place, I knew that the situation was not the same anymore... This is the weakness [of Buddhists], we don’t know what [Muslims] are doing to our religion, or making our religion shrink. I didn't notice this, but when I studied about it in detail I found out that it's a dangerous issue. So we have to find ways to protect our religion (Woman, 38, Buddhist, Myanmar, Lashio, March 2015).

This excerpt illustrates the work that people must do to reconcile the contradiction between the narrative of threat and past experiences with which it is inconsistent. The narrator accomplished this by saying that she had only become aware of the threat from Islam following the riot in Lashio and subsequent "study" with MaBaTha. Variants on this way of resolving contradiction were common, with people describing being newly informed or awoken. If the two religious communities had co-existed peacefully before, according to this telling, it was because narrators did not previously know of the danger within their midst. Many dated this awakening to 2012 or later, though other originating times were also noted, including the popularisation of a book about the dangers of Islam in the late 1990s or the perception that Muslims began emphasising their difference through dress and religious practice in the early 2000s. ${ }^{14}$

The woman at the MaBaTha office in Lashio explained the interpretive work she had done to draw her conclusions about Islam, but other narrators also wrestled with senses of contradiction and drew different conclusions:

I have doubts. That religious conflict [riots in July 2014] was created by the government. But I don’t think they can make it happen again, because people 
have noticed it... Not long ago conflict happened, but I understood what was going on [that it had been manufactured] because Muslims and Buddhists got along in the past. It [July riots] happened out of nowhere (Man, 19, Buddhist, Myanmar, Mandalay, April 2015).

Rather than accept recent violence as an example proving the fearsomeness of a Muslim Other, this young man explicitly rejected this narrative. We heard similar statements in each of the six cities, statements positioned to both reject the idea that violence in a given local area spoke to the "truth” of relations between religious groups and to reject the idea that religion is driving conflict.

The contradiction that we regularly heard articulated, between contemporary tensions and memories of inter-religious coexistence, thus generated explanations that deserve highlighting. The interpretive work necessary to provide such an explanation could reinforce the narrative of Muslim threat, as the above excerpt from the narrator in Lashio illustrates. But it could also result in a rejection of the view that violence is the product of Muslim aggression or irreconcilable Buddhist-Muslim antagonisms. By identifying this contradiction, narrators could make sense of violence in their worlds in ways that also enabled them to claim a past, present and future in which Buddhists and Muslims are not necessarily as at odds. In other words, the contradiction identified formed the basis of an alternative narrative that could contest presentations of Muslims as a threatening Other.

Most commonly, this alternative narrative attempted to explain violence as the product of outside machinations rather than as the local manifestation of antagonism intrinsic to religious groups. Some narrators explicitly named the government, the military or 
individuals within the government or military as behind conflict, though many others did not put a name to their suspicion. Such alternative explanations often included speculation about the reasons for such machinations, where such dark forces would use anti-Muslim fervour to weaken the National League for Democracy or reinstate military rule:

A: Concerning this recent incident [riots in May 2013], we tried to figure it out and later we came to know that it was not created by people from Lashio... It was a relief for us to learn that. We pondered more about this problem with local people from Lashio and discussed it so that things like this won’t happen in the future...

Q: Where do you learn this?

A: Not from any one place, the whole town knows about it. We heard that they have plans, and they implement their plans... It is a good thing that no one from Lashio was involved. We just take care so that such things won't happen in the future (Man, 38, Christian, Kachin, Lashio, March 2015).

Other analysts have noted such alternative interpretations. Some have read them as a kind of rationalising alibi, born from guilt and disbelief that residents of shared communities could be capable of such violence (International Crisis Group 2013, 19). Others have taken them more seriously, echoing our findings and noting powerful statements from people asserting that violence did not characterise their community and would be prevented from occurring again (Centre for Peace and Conflict Studies 2015). Both lines of analysis can be true- the error would be only in a wholesale rejection of the existence of either genuine anti-Muslim sentiment or the existence of alternative narratives. 
What is of central importance is the fact that people are expressing a felt sense of contradiction and making choices about how to respond. The availability of this alternative narrative can make a powerful contribution to promoting peace. Concrete memories of co-existence can form the basis for rejecting universalised arguments about Islam as well as how they are applied to Muslim communities in specific locales. Suspicion that specific political interests and unnamed dark forces have promoted violence can be a way to generate scepticism and critical responses to rumors and other anti-Muslim rhetoric framed in local and national terms. Scholars and others interested in promoting peace should attend to these alternative narratives, for what is at stake is an understanding of the meanings of Islam and Buddhism in Myanmar. Is the former taken to be irreconcilably at odds with the latter? The sense of contradiction and the alternative narrative emanating from some people's responses are not a panacea, but they can enable an answer to this question that can promote reconciliation. This, in turn, relies on articulated memories of inter-communal harmony. The next section of this article will turn to these memories and their relation to scholarship on Myanmar.

\section{CONCLUSION}

We have noted the sense of contradiction that narrators expressed, between articulated memories of past co-existence and present tension. The assertion that concerns about Islam and religious violence are recent, dated to "the Rakhine case” (June 2012) or local violence is consistent. Such assertions were more noticeable outside Rakhine State, but even in Sittwe comparisons between recent violence and an image of a peaceful past were heard. The following excerpt is from a University-educated teacher in Sittwe, who came 
and sat down with us at a teashop, after she had heard we were speaking to another man in the area and volunteered:

In the past, we had students from different ethnicities and religions. Now, we do not have them anymore... We taught them and there was no conflict. We didn't hope that these kinds of things would happen... There was a Bengali issue here in 2012. It is important. One people will swallow another people. So, we have to stop them. As a citizen of Myanmar, I am worried... In the past, I was not so worried as we just lived together. They ["Bengalis”] were also in this section [of the city]... When people are at peace, there is no problem but when they start to have conflict, they become opposed to each other. If you live in a house, if you do not have good relationship with your neighbour, it is dangerous. If you do not have a good relationship, you will do bad things (Woman, 54, Buddhist, Rakhine, Sittwe February 2015).

What do arguments such as these suggest about how the historical lineage of contemporary Buddhist-Muslim violence is being constructed? And what beliefs about the irreconcilability of religious communities do they support? While Muslims have been subject to violence at other times, this is not automatically commensurate with contemporary violence. It is worth considering the relation between contemporary and past violence for two reasons. First, it is significant that people are asserting a contradiction between past and present, regardless of instances of violence or periods of antagonism that have been salient at other times. The point is not the truth of such claims, but that they are made; the fact of the claims-making is significant and should be understood (Portelli 1990). Such assertions are decisions that need to be better 
understood because they serve as a foundation for mobilising alternate narratives that may counter violence. Working for peace and reconciliation would be manifestly more difficult if this contradiction ceases to be expressed, if the two communities are understood to have always been at odds. It would be sad indeed if another Listening Project in a decade's time encountered no narrators who felt that Buddhist-Muslim antagonism contradicted their memories of past co-existence.

Second, individual memories and collective conceptions of history are mutable. This underscores the importance of understanding religious violence in Myanmar not as a prior and ossified set of relationships but as something mobilised in each moment with referents that can change, including notions about history and its relationship to the present. When Das $(1998,113)$ explored the production of fearsome Others in India, she described this as a systematic forgetting. Such forgetting should be a concern in Myanmar. Over the time span of a lifetime, a generation that experiences BuddhistMuslim relations primarily in terms of suspicion and violence would help to establish perceptions of antagonism as primordial fact. In the words of a twenty-year-old activist, reflecting on this sense of contradiction, "Maybe this is true for old people... But we young people have had no chance for remembering this kind of harmony.” Significantly, she is from Kyaukse, an area that was the site of serious Buddhist-Muslim violence during October 2003 (see Al Jazeera, November 3, 2003). ${ }^{15}$

The complement to forgetting is the recasting of old events in a new light and, through this, the creation of new memory. This creation could be accomplished by re-defining previous instances of violence that may not have been collectively interpreted as "religious” violence in those terms. Both processes could contribute to establishing a 
conception of contemporary violence as inevitable and historically determined. Academics, NGOs and media outlets need to be careful that they do not inadvertently bolster such communalisation of conflict as well. It is now well established that assertions of primordial antagonisms by scholars, media, and other observers can contribute to conflict. Lazy and poor historical analogy that equates contemporary violence with, for example, riots in the 1930s reinforces attempts to present religious antagonism as historically determined and irreconcilable. Our research highlights that such contributions can be made in other ways too. Dismissing as conspiracy theory those explanations of violence that highlight the role of the state or unnamed "dark forces," for example, may undermine attempts to promote alternative narratives that counter assertions of threat and antagonism.

Instead of dismissal, scholars should inquire after the specific constellations of conditions that are producing violence and accompanying justifying narratives. Our research underscores the importance of resisting the tendency to assume that present categorisations of groups and their relations can be read back into the past. Instead, in the words of Pandey (1998, ix), “the politics and attitudes that [the assumption of communalisation] seeks to encapsulate have a history which can be charted.” That is, relations between communities now and in the past—-the boundaries drawn between groups that served to define them as apart and together, their relations, and sometimes violence- -have histories that should be studied rather than presumed. Such research would challenge efforts to solidify inter-religious antagonism and facilitate work for reconciliation and peace. 
Ultimately, it is not inevitable that people accomplish this reconciliation of contradiction through a disavowal of relations that cross religious lines. Systematic forgetting is not the only possible outcome. An articulated sense of contradiction between contemporary tension and memories of co-existence can also generate alternative narratives that challenge attempts to emphasise irreconcilability between Buddhists and Muslims. The availability of alternative narratives can also be used to promote peace in specific instances. We would expect to see the operation of similar alternative narratives during the years of the National League for Democracy government. Anti-Muslim rhetoric, rumours, and mobilisation may continue to be rejected by those who take them as not the "truth" of communal relations but as deliberate attempts to disrupt a transition to democracy. On the other hand, for those who feel disaffected or failed by such a transition this counter-narrative may grow less compelling. Indeed, if the primary ground for opposing violence against religious Others is the risk it might pose to democracy or national heroes, this lends additional potential consequences to their perceived failure. 


\section{REFERENCES}

Allard K. Lowenstein International Human Rights Clinic. 2015. "Persecution of the Rohingya Muslims: Is Genocide Occurring in Myanmar’s Rakhine State? A Legal Analysis.” New Haven: Yale Law School.

Benjamin, W. 1986. “Critique of Violence.” In Reflections: Essays, Aphorisms, Autobiographical Writing, edited by P. Demetz, 277-300. Schocken Books.

Braun, E. 2013. The Birth of Insight: Meditation, Modern Buddhism, and the Burmese Monk Ledi Sayadaw. Chicago: University of Chicago Press.

Brooten, L. and Y. Verbruggen. 2017. “Producing the News: Reporting on Myanmar’s Rohingya Crisis.” Journal of Contemporary Asia.

Butler, J. 2003. “Violence, Mourning, Politics.” Studies in Gender and Sexuality 4 (1): 937.

Centre for Peace and Conflict Studies. 2015. This Is Not Who We Are: Listening to Communities Affected by Communal Violence in Myanmar. Siem Reap: Centre for Peace and Conflict Studies.

Chakravarti, N. 1971. The Indian Minority in Burma: Rise and Decline of an Immigrant Community. Oxford: Oxford University Press.

Cheesman, N. 2014. “Democratization, Violence and Myanmar.” In Debating Democratization in Myanmar, edited by N. Farrelly, T. Wilson, and N. Cheesman, 331-49. Singapore: Institute of Southeast Asian Studies.

Coronil, F., and J. Skurski. 2006. States of Violence. Ann Arbor: University of Michigan Press.

Das, V. 1998. “Specificities: Official Narratives, Rumour, and the Social Production of Hate.” Social Identities 4 (1): 109-30. 
Desai, W. 1954. India and Burma, a Study. Calcutta: Orient Longmans.

Duncan, C. R. 2013. Violence and Vengeance: Religious Conflict and Its Aftermath in Eastern Indonesia. Ithaca, NY: Cornell University Press.

Egreteau, R. 2011. “Burmese Indians in Contemporary Burma: Heritage, Influence, and Perceptions since 1988.” Asian Ethnicity 12 (1): 33-54.

Farmer, P. 2004. “An Anthropology of Structural Violence.” Current Anthropology 45 (3): 305-25.

Galtung, J. 1969. “Violence, Peace, and Peace Research.” Journal of Peace Research 6 (3): 167-91.

Government of Burma. 1939. “Final Report of the Riot Inquiry Committee.” Rangoon: Government Printing and Stationery, Burma.

Gravers, M. 2015. “Anti-Muslim Buddhist Nationalism in Burma and Sri Lanka: Religious Violence and Globalized Imaginaries of Endangered Identities.” Contemporary Buddhism 16 (1): 1-27.

Green, P, T. MacManus, and A. de la Cour Venning. 2015. Countdown to Annihilation: Genocide in Myanmar. London: International State Crime Initiative.

International Crisis Group. 2013. The Dark Side of Transition: Violence Against Muslims in Myanmar. Brussels: ICG Asia Report No 251.

Kyaw San Wai. 2014. “Myanmar’s Religious Violence: A Buddhist 'Siege Mentality” at Work.” Singapore: S. Rajaratnam School of International Studies Commentaries No. 037/2014 (February).

Leader Maynard, J. 2014. "Rethinking the Role of Ideology in Mass Atrocities.” Terrorism and Political Violence 26: 1-21.

Maung Zarni, and A Cowley. 2014. “The Slow-Burning Genocide of Myanmar’s Rohingya.” Pacific Rim Law \& Policy Journal 23: 683. 
Min Zin. 2015. “Anti-Muslim Violence in Burma: Why Now?” Social Research: An International Quarterly 82 (2): 375-97.

Nyi Nyi Kyaw. 2016. “Islamophobia in Buddhist Myanmar: The 969 Movement \& AntiMuslim Violence.” In Islam and the State in Myanmar: Muslim-Buddhist Relations and the Politics of Belonging, edited by Melissa Crouch. Oxford: Oxford University Press.

Pandey, G. 1998. The Construction of Communalism in Colonial North India. New Delhi: Oxford University Press.

Portelli, A. 1990. The Death of Luigi Trastulli, and Other Stories: Form and Meaning in Oral History. Albany: State University of New York Press.

Scheper-Hughes, N. 2002. “Coming to Our Senses: Anthropology and Genocide.” In Annihilating Difference: The Anthropology of Genocide, edited by A. Laban Hinton, 348-81. Berkeley: University of California Press.

Scheper-Hughes, N., and P. Bourgois. 2003. Violence in War and Peace: An Anthology. Malden: Blackwell.

Schissler, M. 2014. “May Flowers.” New Mandala. May 17. Accessed July 5, 2015. http://asiapacific.anu.edu.au/newmandala/2014/05/17/may-flowers/.

Schissler, M. 2015. “Some Kind of Feeling.” New Mandala. August 14. Accessed August 14, 2015. http://asiapacific.anu.edu.au/newmandala/2015/08/14/some-kind-offeeling/.

Schissler, M. 2016a. “New Technologies, Established Practices: Developing Narratives of Muslim Threat in Myanmar.” In Islam and the State in Myanmar: MuslimBuddhist Relations and the Politics of Belonging, edited by M. Crouch, 211-233. Oxford: Oxford University Press. 
Schissler, M. 2016b. “On Islamophobes and Holocaust Deniers: Myanmar, the Global War on Terror, and Making Sense of Violence.” In Myanmar: Making Sense of Conflict, edited by N. Cheesman, 285-312. Singapore: Institute of Southeast Asian Studies.

Schissler, M., M. Walton, and Phyu Phyu Thi. 2015. “Threat and Virtuous Defence: Listening to Narratives of Religious Conflict in Six Myanmar Cities.” Oxford: St Antony’s College, Oxford University, Myanmar Media and Society Project Working Paper 1:1.

Schonthal, B and M. Walton. 2016. “The (New) Buddhist Nationalisms?: Symmetries and Specificities in Sri Lanka and Myanmar.” Journal of Contemporary Buddhism, 17 (1): 1-35.

Smith, D. 1965. Religion and Politics in Burma. Princeton: Princeton University Press. Soros, G. 2015. “As a Jew in Budapest, I Too Was a Rohingya.” Newsweek, May 31. Accessed June 21, 2015. http://www.newsweek.com/soros-jew-budapest-i-toowas-rohingya-337443.

Taylor, R. 2015. Refighting Old Battles, Compounding Misconceptions: The Politics of Ethnicity in Myanmar Today. Singapore: Institute of Southeast Asian Studies, ISEAS Perspective 12.

UNOCHA. 2015. “Myanmar: Internal Displacement in Rakhine State (Jan 2015).” UN Office for the Coordination of Humanitarian Affairs (OCHA). Accessed January 1, 2016. http://reliefweb.int/sites/reliefweb.int/files/resources/Affected_Map_IDP_Sites_R akhine_OCHA_Jan2015_A4.pdf.

Walton, M. 2013. “The 'Wages of Burman-Ness:’ Ethnicity and Burman Privilege in Contemporary Myanmar.” Journal of Contemporary Asia 43 (1): 1-27. 
Walton, M., and S. Hayward. 2014. Contesting Buddhist Narratives: Democratization, Nationalism, and Communal Violence in Myanmar. Honolulu: East-West Center Policy Studies (Southeast Asia), No. 71.

Walton, M., M. McKay and Ma Khin Mar Mar Kyi. 2015. “Women and Myanmar’s 'Religious Protection Laws,'” Review of Faith and International Affairs 13 (4): 36-49.

Walton, M., M Schissler and Phyu Phyu Thi. 2017. "Failed riots: Successful conflict prevention in four Myanmar cities,” Oxford: St Antony’s College, Oxford University, Myanmar Media and Society Project Working Paper 1:2. 


\title{
NOTES
}

\begin{abstract}
${ }^{1}$ Over a year after the violence in Meiktila, for example, it was still possible to purchase video CDs with graphic footage celebrating the killing of Muslims, including a sequence with men driving up and down a road full of bystanders, dragging a body behind a motorbike. Mosques in both Sittwe and Meiktila were razed, their foundations barely identifiable when two of the authors visited the areas.
\end{abstract}

${ }^{2}$ Throughout this article we will refer to "religious violence" and "Buddhist-Muslim violence.” This article will make clear that we do this because we see violence being defined in explicitly religious terms. This is different from saying that violence is caused by religion - rather, our point is that objects of fear and antagonism are being defined in religious terms (see Duncan 2013).

${ }^{3}$ The Myanmar Media and Society (M.MAS) project, a partnership between the Programme on Modern Burmese Studies at St Antony’s College, University of Oxford and the Myanmar ICT for Development Organisation (MIDO), and funded by two grants from the National Endowment for Democracy (NED). This article draws upon a M.MAS Working Paper originally circulated in July 2015; the authors are thankful for feedback received, which helped strengthen the arguments presented here.

\footnotetext{
${ }^{4}$ For a discussion of how these locations were chosen, see Schissler, Walton and Phyu Phyu Thi (2015).
}

${ }^{5}$ For further information on the other concerns raised by people in these interviews, see Schissler, Walton and Phyu Phyu Thi (2015). 
${ }^{6}$ A very small number of Muslims in Rakhine State have been granted citizenship if they identify as "Bengali" and can provide documentation to demonstrate that they meet the requirements defined in Myanmar’s 1982 citizenship law. Yet even this population has not been allowed the freedom of movement and other rights that go along with citizenship (see The Irrawaddy, June 16, 2015).

${ }^{7}$ In Burmese, Mye myo ywè lu myo ma pyôk lu myo hma lu myo pyôk mè. Note that, although lu myo can be translated as "nation,” “ethnicity” or “people,” here we understand it to refer to "nation."

${ }^{8}$ There is no consistent doctrinal position within Myanmar Buddhism regarding the consumption of beef. However, cows are revered by many and, for some Buddhists (and all Hindus), beef is taboo (see Myanmar Now, August 3 2015).

${ }^{9}$ Interview subjects are identified by (Sex, Age, Religion, Ethnicity, Location, Date). Designations for religion and ethnicity are presented as stated by the narrators, even where they do not correspond to identifications recognized by the Myanmar government. (For example, many of our interviewees gave their ethnicity as “Myanmar,” which is technically a designation of national identity.)

${ }^{10}$ Here the narrator is referring to the fact that many Buddhists in Myanmar traditionally have a shrine in the east their home- - the head of the home (ein gaung yin); the complaint is that Muslims sleep with their feet pointing to the east, which is felt to be deeply disrespectful by people for whom feet are culturally dirty. 
${ }^{11}$ The word kalar is controversial. Most contemporary Burmese language dictionaries list the primary definition as “person from South Asia.” But the term’s etymology is contested, with two primary interpretations. First, that kalar is derived from Pali ku-la, where $k u$ indicates “crossing maritime space” and la indicates “to come.” Thus foreigners arriving via the ocean were identified as $k u$-la, which would include both foreigners from South Asia as well as Arab traders. Consistent with this is the fact that "kalar" has been used to refer to both people of apparently South Asian descent as well as light skinned foreigners (kalar phyu, or “white kalar” as well as Ingaleit kalar, or "English kalar”) who would also have arrived via the sea. In contrast, foreigners arriving from China or Thailand—both land routes rather than sea—are never referred to as "kalar." A variant of this is that kalar in Pali scriptures is used to mean "noble” or "pure," in relation to the Buddha's lineage, originating in present-day India. The second interpretation is that kalar is derived from the Sanskrit word for "black," used in both Hindi and Urdu, and was thus adopted to refer to persons with dark skin. For a summary of these debates (Egreteau 2011, 46-48). See also Chakravarti (1971, 11); Desai (1954, 37-38); Taylor (2015, 4). Etymological controversies aside, while many feel that the term is not intrinsically pejorative others feel that current usage is and strongly so. Dr Maung Zarni, for example, uses the American English word "n---er” as a translation that emphasises the negative rhetorical force of the word and while the appropriateness of such a choice might be debated it is consistent with other scholarship that has drawn comparisons between racial politics in the United States and dynamics between Burman and non-Burmans in Myanmar (See Walton 2013). One Muslim narrator in Mawlamyine, meanwhile, offered the following reflection on being referred to as "kalar": "Since I was studying... if you're small, they'd call you kalar lay ('small kalar'), if you're strong and big, you'd be called 
kalar gyi ('big kalar'). There weren’t many Muslims at my school, only a couple Muslims in one class. We had some good [non-Muslim] friends but there were also naughty ones, however there was nothing like being badly discriminated or something. I still felt something when I was called 'kalar'. But I can understand them because it's a habit for them, calling us 'kalar.’ However, they don’t know how we feel” (Man, 34, Muslim, “Pathi,” March 2015, Mawlamyine).

${ }^{12}$ In this case, the "they" she refers to throughout the interview she defines as "Bengalis," which is the way many in Rakhine-and across Myanmar-refer to people who are seeking to be recognised as Rohingya. This is also the terminology used by state officials, who have steadfastly maintained that those seeking recognition as Rohingya are illegal immigrants from Bangladesh.

${ }^{13}$ In 1938, for example, riots in Rangoon and across lower and middle Burma left at least 1,284 dead or injured, many of who were Muslim (Government of Burma 1939, 281). In a passage that could describe contemporary Myanmar, Smith $(1965,110)$.described a scene at Shwedagon Pagoda before the riots: “Over 10,000 people, including 1,500 monks, passed a resolution demanding that the author [of a book insulting Buddhism] be punished, warning that if the government should fail to take necessary action 'steps will be taken to treat Muslims at enemy No. 1 who insult the Buddhist community and their religion, and to bring about the extermination of the Muslims and the extinction of their religion and language'.”

${ }^{14}$ Published under the name Disappearance of the Race is a Thing to Fear (A-myo pyauk hma so kyauk saya), this booklet (sometimes broken into a series of smaller volumes) 
consisted of arguments about the risk that Buddhism faces from Islam, including apocryphal stories of Muslims committing alleged crimes against Buddhists and the loss of Buddhism in other places across the world.

${ }^{15}$ Notably, U Wirathu also hails from Kyaukse and was sentenced to 25 years in prison for inciting this violence. He was released in early 2012. 